\begin{abstract}
Resumo
Este artigo analisa dois textos escritos pelo filósofo francês Jean-Paul Sartre, a saber, New York cidade colonial e Cidades da América, escritos após uma viagem do autor aos Estados Unidos da América em 1945. Estes textos são as únicas obras do filósofo francês que tratam, quase exclusivamente, do tema da arquitetura e do urbanismo. Por outro lado, estes textos compõem um gênero literário específico, a chamada "narrativa de viagens", e nesta condição possuem códigos específicos e regras próprias. Assim, neste artigo as descrevemos e listamos os seus topos mais freqüentes. Após isto, foram analisadas as observações que o filósofo fez da arquitetura e das cidades norte-americanas.
\end{abstract}

Palavras-chave: cidades norte americanas, arquitetura norte americana, filosofia francesa.

\section{ntrodução: algumas considerações sobre as narrativas de viagem}

Mon bateau partira demain pour l'Amérique Et je ne reviendrai jamais Avec l'argent gagné dans les prairies lyriques Guider mon ombre aveugle en ces rues que j'aimais ${ }^{1}$ para a América/ E eu não voltarei nunca mais/Com o dinheiro ganho nas pradarias líricas/ Guiar minha sombra cega nestas ruas que eu amava." Tradução nossa do Francês para o Português. Para maior detalhes ver Referências.

2 Trata-se dos textos New york ville coloniale e Villes d'Amérique, ainda sem tradução para o Português do Brasil. Para mais detalhes, ver Referências

Guillaume Apollinaire. L'imigrand de Landor Rod

Este artigo tem o objetivo estudar dois textos que o filósofo francês Jean-Paul Sartre publicou após a viagem que realizou em de 1945 aos Estados Unidos da América, os quais apresentam as impressões do filósofo francês sobre a arquitetura e as cidades norte-americanas ${ }^{2}$. Estes textos são as únicas obras do filósofo francês que tratam, quase exclusivamente,

\section{Adson Cristiano Bozzi Ramatis Lima}

Arquiteto e urbanista, professor assistente da Universidade Estadual de Maringá, Departamento de Arquitetura e Urbanismo, Av. Colombo, 5790, Zona 07, CEP 87020-000, Maringá, PR, (44) 3261-44-29, a.bozzi@uol.com.br a chamada "narrativa de viagens" ou "literatura viática", e, nesta condição, possuem um código específico com as suas regras próprias. Assim, e por uma questão de lógica interna a própria exposição, antes de abordar o tema da arquitetura e das cidades norte-americanas estudaremos as especificidades deste gênero literário. o tema da arquitetura e do urbanismo. Por outro lado, estes compõem um gênero literário específico,
Tendo em mente esta questão, convém iniciar as nossas argumentações pela importância das viagens no pensamento do filósofo francês. Sartre foi aos Estados Unidos da América pela primeira vez na condição de jornalista, em 1945, a convite do estado maior americano, quando a Segunda Guerra Mundial ainda não tinha terminado. Ora, se pensarmos na "americanofobia" que o filósofo francês desenvolveu já no início da década de 1950, este fato pode espantar, mas devemos ter em mente que, no século $X X$, a "América" era um mito a 
${ }^{3}$ Sartre empreendeu sete viagens a União Soviética: nos anos de 1954, 1955, 1962, 1963, 1964, 1965 e 1966. Depois, assim como já ocorrera com os Estados Unidos da América a partir de 1946, as suas relações com o país socialista se tornam cada vez frias, até o rompimento definitivo que tem lugar em 1968, com a intervenção soviética em Praga. Para mais detalhes consultar: Lévy, BernardHenri. O século de Sartre. Rio de janeiro: Nova Fronteira, 2000

${ }^{4}$ Em uma entrevista concedida a Simone de Beauvoir em Agosto-Setembro de 1974 Sartre assim descreve o seu desejo de lecionar no Japão: "Esse cargo no Japão estava livre, ofereciam-no. Não é que tenha pedido para ir. O diretor da Escola recebera a missão de escolher um aluno que quisesse ir para o Japão e que assumiria, em Kyoto, o cargo de professor de francês em uma escola japonesa. Candidatei-me. Isso me parecia absolutamente normal. Quando você me conheceu..." Beauvoir retorqui: " Cogitava-se de que nos separaríamaos para que você passasse doía anos no Japão. E você ficou muito triste por não ter ido..." In: Beauvoir, Simone de. A cerimônia do adeus. Trad.: Rita Braga. Rio de Janeiro: Nova Fronteira, 1984, p. 315. Em seu livros de memórias ela nos narra: "Entretanto ia ser obrigada, muito em breve, a iniciá-lo [um trabalho para recuperar o equilíbrio], e a perspectiva tranqüilizava-me. A felicidade em que me debatia era precária, porquanto Sartre contava partir para o Japão." In: Beauvoir, Simone de. A força da idade. Trad.: Sérgio Millet. Rio de Janeiro: Nova Fronteira, 1984, p. 68.

${ }^{5}$ Lê-se em "nota dos editores": "Nessa época, Antoine Roquentin, após haver viajado pela Europa central, África do Norte e Extremo Oriente, tinha-se fixado havia três anos em Bouville para aí concluir suas pesquisas históricas sobre o marquês de Rollebon." Tradução do Francês para o Português de Rita Braga.

${ }^{6}$ Tradução nossa do Francês para o Português. No original lê-se: "Je vais de ville em ville, étranger aux autres et à moimême, et les villes se assombrar o imaginário de não poucos europeus, e, além disto, Sartre possuía um espírito viajante: em cerca de cinco décadas vários países foram por ele visitados: Alemanha (1933, 1954 e 1974), Estados Unidos da América (1945 e 1946), Islândia (1946), Canadá (1946), Cuba (1949 e 1960), Áustria (1952), China (1955), Brasil (1962), Japão (1966), Egito (1967) e Israel (1967), e a alguns países o filósofo francês empreendeu incontáveis viagens, como a União Soviética e a Itália. Certamente que não causa espanto o fato que um intelectual europeu tenha viajado a Áustria, a Alemanha e a Itália, mas temos que admitir que o número de viagens e as viagens a países que estavam, na época, fora do circuito turístico, como Israel, Cuba e União Soviética, é incomum mesmo para europeus com possibilidade de mobilidade internacional - e é mesmo surpreendente que ele tenha conhecido praticamente todas as repúblicas soviéticas ${ }^{3}$. Além disto, corrobora a nossa afirmação sobre o desejo viajante de Sartre que em outubro de 1931 ele havia concorrido a um posto de professor no... Japão! ${ }^{4}$ Mas não seria o caso, aqui, de enumerar todas as viagens realizadas por Sartre, o que pretendemos é apenas sustentar a nossa argumentação sobre a importância das viagens no universo cultural sartriano.

Mesmo nas suas peças e romances a perspectiva das viagens ronda grande parte das suas personagens. A personagem Antoine Roquentin da novela $A$ náusea é um bom exemplo: havia viajado pela Europa central, África do Norte e Extremo Oriente, antes de, finalmente, estabelecer residência na cidade ficcional de Bouville, a qual, segundo os críticos, teria sido inspirada na cidade francesa de Havre, onde Sartre havia trabalhado como professor de Liceu ${ }^{5}$. Oreste, personagem da peça teatral Les mouches, exclama: "Eu vou de cidade em cidade, estrangeiro aos outros e a mim mesmo, e, atrás de mim, as cidades se fecham novamente como uma água tranqüila. " 6 Trata-se, como se pode perceber, de uma imagem clássica da viagem como errância, une espécie de flânnerie levada a um território que não é mais o coração das cidades, mas um espaço expandido. Citaremos, agora, e à guisa de ilustração, um breve extrato do romance L'âge de raison, publicado pela primeira vez em 1939, no qual se lê o seguinte diálogo entamado entre duas personagens, Mathieu Delarue e Ivich Serguine:
[Mathieu]:

_ Você quer dizer que eu sou um deles [pequeno burguês]? Pergunta alegremente. Pois bem, você vê que isto explica tudo. Talvez um belo dia eu parta para o Taiti.

Ivich se vira para ele e o olha direto no rosto. Ela não parecia bem e tinha medo: ela devia estar com medo da sua própria audácia.

_ Isto me surpreenderia, disse com uma voz branca. _ Porque não? Disse Mathieu. Talvez não o Taiti, mas a New York. Eu gostaria muito de ir a América.

Ivich puxava os cachos do seu cabelo com violência.

_ Sim, disse ela, se fosse em missão... com outros professores.

Mathieu a olha em silêncio e ela continua:

_ Talvez eu esteja enganada... Eu posso imaginar você muito bem fazendo uma conferência em uma universidade diante de estudantes americanos, mas não no convés de um barco com imigrantes. Talvez porque você seja francês. ${ }^{77}$

Ambas as personagens estavam em uma exposição do pintor Gauguin, este grande exilado ${ }^{8}$ - e a este fato se deve a referência ao Taiti - e, de alguma maneira, Ivich é estrangeira na França, pois o seu pai era um nobre russo que foi para o exílio depois da Revolução de 1917; o que explica a sua reposta a Mathieu: "Talvez porque você seja francês". Ela, nascida na França de pais russos não se sentia francesa, assim como o pintor francês no Taiti ela era uma exilada em terras estrangeiras ${ }^{9}$.

Parece que voltamos a escrever sobre a errância, mas o que nos interessa no diálogo citado é justamente a confirmação do que afirmamos tão peremptoriamente no caput deste texto, isto é, o espírito viajante de Sartre. Ora, já afirmamos neste artigo que Sartre realizou duas viagens aos Estados Unidos da América, e que na primeira ele foi na condição de jornalista à convite do estado maior americano, mas ele viajou, igualmente, na condição de escritor e de professor. ${ }^{10}$ Assim, deve-se observar a acusação que Ivich fez a Mathieu: que ele seria um mero "escritor de domingo" animado por uma estreita mentalidade pequeno burguesa, e que redigiria a sua novela anual e os seus cinco ou seis 
referment derrière moi comme une eau tranqüille..." (apud Jeanson, 2000, p. 9).

7 Tradução nossa do Francês para o Português. No original lê-se: "_Vous voulez dire que je suis un [petit bourgeois]? Demanda-t-il gaiement. Eh bien, vous voyez que ça mène à tout. Peut-être qu'un beau jour, je partirai à Tahiti. Ivich se torna vers lui et le regarda bien em face. Elle avait I'air mauvais et apeuré: elle devait s'éffrayer de sa propre audace. _Ça m'étonnairait, dit-elle d'une voix blanche. Pourquoi pas? Dit Mathieu. Peut-être pas à Tahiti, mais à New-York. J'aimerai bien aller em Amérique. Ivich tirait ses boucles avec violence. __ Oui, dit-elle, si c'était en mission... avec d'autres professeurs. Mathieu la regarde em silence et elle reprit:__Peut-être que je me trompe... Je vous imagine très bien faisant une conference dans une université devant des étudiants américains, mas pas sur le pont d'un bateau avec des émigrants.

C'est peut-être parce que vous êtes français" (1972, p. 98). Talvez nesta observação da personagem Ivith ecoe a seguinte experiência sartriana narrada por Beauvoir a propósito de uma viagem realizada a Grécia no ano de 1935: "Embarcamos no Cairo City e observamos que, entre os passageiros do convés, se operava espontaneamente uma segregação; os pobres emigrantes que voltavam para o seu país amontoavam-se na proa com seus sacos e fardos; os turistas, pouco numerosos, descansavam na popa." In: Beauvoir, Simone de. A força da idade. Trad.: Sérgio Millet. Rio de Janeiro: Nova Fronteira, 1984, p. 302. Na viagem de retorno o mesmo fenômeno foi observado.

${ }^{8}$ Ivich pergunta repentinamente a Mathieu: "Foi ele quem... partiu (1972, p. 97)? Tradução nossa do Francês para o Português. No original lê-se: "C'est lui qui est. parti?" É banal afirmar que aquele que parte inscreve a errância no seu destino, mas isto pode ser vivido, igualmente, como uma maldição: quando Gauguin quis retornar a Paris não o pôde porque as suas pinturas vendiam principalmente devido o exotismo poemas por ano fazendo-o como uma espécie de higiene - e que viajaria, na sua "cabine de segunda classe" , na condição de professor. Ora, este trecho ficcional se torna significativo se pensarmos que o seu autor viajou para a "América" na condição de professor e proferiu duas palestras para o público americano... Não que o filósofo francês fosse um "escritor de domingo" - aliás, pelo contrário, todos sabemos que ele era extremamente prolixo -, mas não deixa de ser curioso que ele tenha, em 1945, cumprido o destino que ele - na voz de Ivich - teria traçado para Mathieu em 1939... Ann Fulton, historiadora norte-americana da Portland State University, e que estudou a influência do Existencialismo nos Estados Unidos da América, afirmou:

Peyre [professor da Universidade de Yale] convidou Sartre para uma palestra quando soube que o filósofo seria um dos sete jornalistas franceses trazidos pelo setor de informação do estado maior para relatar o esforço de guerra nacional. (...) Sartre proferiu duas palestras em Yale no mês de Abril de 1945; a primeira sobre literatura e a segunda sobre filosofia. ${ }^{11}$

Neste sentido, seria interessante que investigássemos o que Sartre conhecia dos Estados Unidos da América, posto que isto nos ajudará a compreender a percepção que Sartre se formou deste país. Ora, sabemos por Fulton que o filósofo francês era conhecido nos Estados Unidos da América, em 1945, apenas por um público acadêmico restrito, e que a ignorância da língua francesa por parte dos norte-americanos e a ausência de tradução das suas obras para o Inglês foram os principais empecilhos para que um contato mais efetivo se estabelecesse. ${ }^{12} \mathrm{E}$ é curioso observar que muitos acadêmicos norte-americanos apenas tiveram contato com Sartre e com o Existencialismo porque estavam servindo no exército norteamericano na Europa, e quando retornaram ao seu país implementaram cursos sobre o filósofo francês (Fulton, 1999, p. 21). É interessante este caráter "outro" das guerras, que é a disseminação cultural que se dá a partir do encontro com a alteridade.

Ainda em relação à Segunda Guerra Mundial, há que se levar em consideração um ponto importante: a França havia sido derrotada pela Alemanha já em 1940, e todos aqueles que não queriam viver sob ocupação e nem na França de Vichy e que poderiam partir, escolheram o exílio. Assim, havia um número nada desprezível de intelectuais franceses nos Estados Unidos da América: o romancista SaintExupéry, o poeta Saint-John Perse, o cineasta Jean Renoir, o historiador Paul Hazard, o explorador e escritor Paul Émile Victor, entre outros. Embora alguns não dominassem com propriedade o Inglês ${ }^{13}$, o que sempre dificulta intercâmbios culturais mais profundos, e apesar de estarem profundamente divididos em facções politicamente opostas e rivais - a maior disputa se dava entre os partidários do general de Gaulle e os do general Giraud ${ }^{14}$ - é inegável que a presença de intelectuais franceses importantes tenha contribuído para despertar uma maior curiosidade dos norte-americanos em relação à cultura francesa.

Mas havíamos aludido ao conhecimento que Sartre possuía dos Estados Unidos da América em meados da década de 1940, tema sobre o qual ainda não escrevemos. Ora, sabe-se pelo seu livro de memórias As palavras, publicado pela primeira vez em 1960, que o filósofo francês tinha uma principal fonte de conhecimento deste país: a sua literatura ${ }^{15}$. E esta, por sua vez, bifurca-se, há o que ele chamava de "suas más leituras" de infância, e a alta literatura consumida ainda jovem. A despeito da auto ironia deste livro, que é, na realidade, a sua despedida da literatura, pode-se perceber a importância do mundo das letras na formação do jovem Sartre: "Mas os livros foram meus passarinhos e meus ninhos, meus animais domésticos, meu estábulo e meu campo; a biblioteca era o mundo colhido num espelho; tinha a sua espessura infinita, a sua variedade e a sua imprevisibilidade (1984, p. 37) ${ }^{16}$. Esta citação é convincente o suficiente para nos permitir afirmar que o espaço que a literatura ocupou no mundo intelectual do jovem Sartre era considerável e significativo ${ }^{17}$. Mas isto não é nenhuma novidade, afinal, afirmar que aquele que viria ser um dos mais influentes intelectuais do século XX lia bastante na juventude é até um tanto redundante. Mais importante seria saber o que, efetivamente, Sartre consumia como literatura. Então, o que lia o futuro filósofo francês? Como veremos, um pouco de tudo...

Tive encontros horriveis: abria um álbum, topava com uma prancha em cores, insetos horriveis pupulavam sob minha vista. Deitado sobre o tapete, empreendi áridas viagens através de Fontenelle, 
que os franceses percebiam nelas. Ele viajou e viu "coisas raras", teriam pensado.

${ }^{9}$ Mathieu constrói uma espécie de "vida paralela" para Ivich, pensando no seu destino se não tivesse havido a Revolução de 1917: "Sem a revolução de 1917, Ivich teria sido educada em Moscou, em um pensionato para as senhoritas da nobreza; ela teria sido apresentada à corte, ela teria casado com um oficial da guarda, alto e belo, com um rosto estreito e um olhar morto." Tradução nossa do Francês para o Português. No original lê-se: "Sans la révolution de 1917, Ivich aurait été élevée à Moscou, au pensonnat des demoiselles de la noblesse; elle aurait été présentée à la cour, elle aurait épousée um officier de la garde, grand et beau, au front étroit, au regard mort" (1972, p. 97). Ao contrário disto, lá estava Ivich, em uma exposição sobre Gauguin, em Paris, com um professor francês, e o seu pai - nobre na Rússia - tinha uma pequena serralheria na cidade provincial de Laon.

${ }^{10}$ Estas viagens realizadas em 1945 e 1946 não são de pouca importância se pensarmos no ativista político radical que estava em gestação - e a frase de Simone de Beauvoir no seu livro de memórias no-lo atesta: "Assim é que paradoxalmente éramos atraídos pela América, cujo regime condenávamos, e a URSS, onde se desenrolava uma experiência que admirávamos, nos deixava indiferentes." In: Beauvoir, Simone de. A força da idade. Trad.: Sérgio Millet. Rio de Janeiro: Nova Fronteira, 1984, p. 143.

${ }^{11}$ Tradução nossa do Inglês para o Português. No original lê-se: "Peyre invited Sartre to lectute at Yale when he learned that the philosopher would be one of the seven French journalists brought over by Office of War Information to report on the national war effort. [...] Sartre delivered two lectures at Yale in April 1945; the first dealt with philosophy and the second with literature" (1999, p. 23).

12 O público destas duas palestras foi composto, majoritariamente, por acadêmicos de literatura, uma vez que os filósofos norte-americanos não tinham conhecimento o
Aristófane, Rabelais: as frases resistiam-me à maneira das coisas; cumpria observá-las, rodeálas, fingir que me afastava e retomar subitamente a elas de modo a surpreendê-las desprevenidas; na maioria das vezes, guardavam o seu segredo. Eu era La Pérouse, Magalhães, Vasco da Gama; descobria estranhos indígenas: "Heautontimorumenos" numa tradução de Terêncio em alexandrinos, "idiossincrasia" num livro de literatura comparada. (1984, p. 37 - destaque nosso)

Baseado neste extrato pode-se escrever sobre o "viajante imóvel", que mesmo em torno do seu quarto encontra espaço para o desconhecido e o insólito: "Heautontimorumenos" e "idiossincrasia". É necessário que se diga que há inúmeras maneiras de viajar, e estas foram as viagens do jovem Sartre no nível da alta literatura, mas nem só de Rabelais e Aristófanes vive um jovem francês... ${ }^{18}$ Há que se referir, igualmente, as suas já aludidas "más leituras", e que eram terminantemente proibidas pelo seu avô. Esta literatura, todavia, consistia somente naquela que, hoje, em nosso país, é chamada de "infanto-juvenil":

Durante um de nossos passeios, Anne-Marie parou como que por acaso diante da banca que ainda se encontra na esquina do bulevar Saint-Michel e da rua Soufflot: vi imagens maravilhosas, suas cores gritantes fascinaram-me, pus-me a exigi-las e as obtive; a peça estava pregada: todas as semanas eu queria o Cri-Cri, L'Epatant, Les Vacances, les Trois Boy-scouts de Jean de la Hire e A Volta em Aeroplano de Arnaud Galopin que apareciam em fascículos às quintas-feiras, [...]. Minha mãe pôs-se a procurar obras que me devolvessem a infância: houve primeiro "os livrinhos rosa", coletâneas mensais de contos de fada, depois, pouco a pouco, Os Filhos do Capitão Grant, O Últimos dos Moicanos, Nicolas Nickleby. Os Cincos Soldos de Lavarède. A Jules Verne, ponderado demais, eu preferia as extravagâncias de Paul d'Ivoi . (1984, p. 54)

Esta longa citação é importante na economia da nossa exposição porque, além de através dela podermos conhecer o vívido prazer, e mesmo êxtase, que Sartre confessa ter sentido ao folhear as páginas destes "livrinhos", abre-nos caminho para o fim que realmente nos interessa: a sua relação com os Estados Unidos da América. Como sabemos, em todo contato com o estrangeiro há a cultura que observa e aquela que é observada, e conhecer a imagem que Sartre se formou do país americano, quando jovem, nos permitirá compreender com mais clareza as narrativas que ele escreveu e publicou após o seu retorno a França. Neste sentido, é mister que conheçamos a "América" da sua infância... Ei-la:

O Novo Mundo parecia a princípio mais inquietante do que o Antigo: pilhava-se nele, matava-se, o sangue corria aos borbotões. Índios, hindus, moicanos, hotentotes raptavam a donzela, amarravam o seu velho pai e prometiam fazê-lo perecer sob os mais atrozes suplícios. Era o puro Mal. Mas ele só aparecia para prosterna-se perante o Bem: no capítulo seguinte, tudo ficaria restabelecido. Brancos corajosos procederiam a uma hecatombe de selvagens, cortando as cordas do pai, que se jogaria nos braços da filha. Apenas os maus morriam - e alguns bons muito secundários cujo procedimento figurava entre as despesas imprevistas da história. (1984, p. 55 - destaque nosso)

Estas irônicas frases lançam-nos em um país mítico cuja fabricação se destinava a um público juvenil não era, certamente, o Pays de Cocagne, mas nem por isto era menos idealizado e menos onírico. Pode-se afirmar que o continente americano jamais cessou de despertar curiosidade e fascínio no público europeu e sempre houve um "espaço outro" idealizado e, não raras vezes, estereotipado: vastas extensões territoriais a serem desbravadas, índios não civilizados, brutalidade e violência - o Mal, enfim... Ou, dito de outra maneira, o "outro"19. Ou, ainda, o constante companheiro de viagem do estereótipo, o exotismo, o qual pode ser encontrada em grande número nas narrativas de viagem sobre a América do Norte. ${ }^{20}$ A observar que a passagem descrita por Sartre é um "estereótipo de natureza exótica": selvagens violentos versus brancos corajosos ${ }^{21}$. Ora, argumentará o leitor, todos os estereótipos são exóticos, posto que é justamente o exotismo a principal razão para o surgimento do estereótipo, uma vez que se trata de uma compreensão às vezes falsa, outras tantas vezes simplificada, do estrangeiro. Seja, mas é necessário reconhecer que se todo estereótipo comporta boa parte de incompreensão, nem todos são exóticos. Se para o europeu o ameríndio tornava- 
suficiente do Francês oral e não havia tradução simultânea. As primeiras traduções de Sartre para o Inglês foram as peças teatrais Huis Clos (No Exit) e Les Mouches (The Flies) no ano de 1947. A sua obra filosófica de maior importância na época, L'Être et le Néant, teve a sua tradução completa para o Inglês apenas no remoto ano de 1956 (Fulton, 1999, p. 25)

${ }^{13}$ Segundo o tradutor francês Henri Delgove, Saint-Exupéry teria feito a seguinte afirmação, a respeito da sua mais absoluta ignorância em relação à língua inglesa: "Um escritor francês não deve estragar a sua língua" (1984, p. 29). Em uma carta a Curtice Hitchcock, de 8 de junho de 1943, quando havia deixado o exílio na América do Norte e estava em Udjda combatendo as forças nazistas, SaintExupéry escreve: "Levo exatamente a vida de um acampamento norte-americano e... aprendo inglês!" (1984, p. 365). Traduzido do Francês para o Português por Vera Guimarães Duarte. Sartre, por sua vez, nos anos 1945 e 1946, também não dominava o Inglês; à pergunta de Beauvoir se o fato de não domina-lo não o incomodava, respondeu: "Não, porque só estava com americanos que falavam francês; os outros me ignoravam como alguém que não conhecia a língua, é natural" In: Beauvoir, Simone de. A cerimônia do adeus. Trad.: Rita Braga. Rio de Janeiro: Nova Fronteira, 1984, p. 331.

${ }^{14} \mathrm{O}$ professor francês Leon Wencélius afirma no diário que escrevia em 1941, no seu exílio norte-americano: "os franceses da América tinham voltado à época das guerras de religiões" (1984, p. 185). Denis de Rougemont, por sua vez, escreve no seu diário no ano de 1942: "Quanto aos gaullistas daqui, eles não combatem os nazistas, mas sim o ascensorista francês do Waldorf ou o chefe de cozinha do Ritz que se recusam a aderir a sua facção e a quem tomam por traidor" (1984, p. 249). Traduzido do Francês para o Português por Vera Guimarães Duarte.

15 Bernard Henri-Lévy nos adverte para não nos fiarmos em demasia Nesta autobiografia: "Contrariamente às narrações do mesmo gênero, contrariamente a todas as se o "bom selvagem" 22 , que é, certamente, um "estereótipo de natureza exótica", para o norte americano o termo uncle Tom nada apresenta de exótico $^{23}$

Mas há uma questão envolvendo esta imagem estereotipada da América do Norte evocada por Sartre e que é interessante: é certo que não havia mais no seu imaginário - a não ser, evidentemente, como memória - "selvagens" e aventuras de Far West, mas, mesmo assim, é curioso observar uma certa permanência residual em seu discurso quando se trata de analisar New York, descrita como "a cidade mais rude do mundo" 24

A natureza pesa tão gravemente sobre New York que a mais moderna das cidades é também a mais suja. [...] Quando eu saio, caminho em uma neve escurecida, uma espécie de crosta empolada com a mesma coloração da calçada, ao ponto de acreditarmos que é a própria calçada que está empenada. Desde o fim de Maio o calor se abate sobre a cidade como a bomba atômica. É o Mal. ${ }^{25}$ (destaque nosso)

É justamente esta fragilidade da cidade de New York face aos elementos da natureza que levou o filósofo francês a nomear o seu texto viático New York ville coloniale - e não deixa de ser curioso observar que Sartre teve a sua experiência de colono francês na América... Parece que exageramos, mas é fato que a presença de uma natureza descrita como "hostil, surda, misteriosa" no coração mesmo da cidade o incomodava enormemente: "Eu acredito estar acampado no coração de uma floresta fervilhando de insetos." 26 Tudo o incomodava: as descargas elétricas que recebia ao apertar um botão ou a mão de um amigo, as baratas na sua cozinha, os elevadores que the causavam náusea, a sede insaciável que sentia pela manhã... E depois de comparar o calor nova-iorquino a uma explosão atômica, resumiu o seu mal-estar com a fórmula: "É o Mal". Não devemos esquecer que Sartre escreveu isto no ano de 1945, e a lembrança dos horrores de Hiroshima tinha, ainda, a força de um impacto moral. E é interessante notar que a mesma fórmula está presente na descrição da América do Norte no seu imaginário infantil: "É o puro Mal". Ora, a palavra "mal" grafada com letra maiúscula torna-se um conceito filosófico. E se não há mais elementos que possam ser compreendidos como estereótipos, há que se convir que os selvagens impiedosos foram substituídos - na categoria do Mal - pela sede e pelo calor (e, a julgar pela menção às baratas, tampouco há brancos corajosos....).

Mas como já havíamos aludido, Sartre nem sempre se nutriu de estereótipos, posto que cedo teve acesso à alta literatura norte-americana. Admirava profundamente os escritores John dos Passos e William Faulkner, e a eles dedicou alguns estudos ${ }^{27}$. Neste sentido, é interessante observar que Sartre, por sua vez, reproduziu um estereótipo em relação aos Estados Unidos da América. No estudo Sartoris, de William Faulkner, afirma que, no romance homônimo, o que anima as personagens é o tédio $\left(\right.$ ennui ${ }^{28}$. No entanto, esta palavra não é encontrada neste romance, e é possível afirmar que se trata apenas de uma interpretação realizada por um crítico cuja tradição literária é distinta daquela da qual o romance analisado pertence. É claro que não necessariamente a palavra - no caso, tédio (ennui) - tenha que estar presente para que a sensação seja evocada, apenas chamamos atenção para o seguinte fato: pensar o outro é pensar em si mesmo, isto é, pensar a partir de uma espécie de "filtro cultural"29. A observar, igualmente, que o tédio é um topos importante na literatura francesa ${ }^{30}$, mas percebido por um europeu na literatura norteamericana do século XX - e, como veremos, no próprio país - torna-se apenas um estereótipo levemente exótico...

Pode parecer, todavia, que fizemos uma afirmação inconsistente, uma vez que apresentamos poucos argumentos e apenas um único caso... Mas há espaço o suficiente neste texto para que possamos ampliar o alcance das nossas argumentações, e, neste sentido, podemos convocar a narrativa Villes d'Amérique, na qual o filósofo francês vaticina: “É preciso não esquecer o espesso tédio [ennui] que pesa sobre a América, " para explicar um restaurante no qual as pessoas faziam a refeição em silêncio. Esta frase incisiva, e que aparentemente não deixa margens para dúvida, só foi possível porque Sartre já havia interpretado desta maneira certos romances norte americanos - Le Corbusier, diante da mesma cena, e na mesma cidade, New York, limitou-se a dizer: "Os restaurantes americanos são silenciosos"... E completou: "eu me entedio."31 Isto significa que o que Sartre percebeu teria sido apreendido de maneira distinta por um estrangeiro 
biografias de escritores que, por mais barrocas que sejam, conservam, pelo menos quanto aos fatos, alguma forma de coerência e de ordem, essa vem adornada, já em sua construção, por mil anomalias narrativas, retomadas, erros aparentes de construção, lembranças falsas ou adulteradas, aberrações cronológicas, mentiras, pequenas trapaças, inverossimilhanças, contradições de todo tipo, guinadas, projeções bruscas no futuro, voltas atrás injustificáveis - tudo isto com um tom de humor clínico, quiçá cínico, sem complacência, sem verdadeira emoção, que, impregnando, salvo algumas exceções (as relações com Anne-Marie...), o essencial do relato, aproxima-o de um pastiche, ou de uma paródia do gênero, mais do que da expressão de alguma obscuridade interior, por muito tempo cultivada como tal, preservada como um tesouro ou um segredo, mantida em sua opacidade e que se resolvera, de repente, esclarecer" ( 2001, p. 510)

${ }^{16}$ Todas as traduções dos trechos citados desta edição são de autoria de J. Guinsburg.

17 Segundo Bernard HenriLévy trata-se de um livro que Sartre escreveu para exorcizar de si mesmo a "doença da literatura" adquirida na infância: "Ele já se operara da filosofia. Opera-se, agora, da literatura. Reconvertido aos anos trinta, mas acrescentando mais ódio, aumentando a aposta, aqui o temos duplamente amputado" (20001, p. 531).

${ }^{18}$ No livro O que é a literatura, publicado pela primeira vez em 1948, Sartre escreve sobre a sua relação com a literatura: "Mas nós, bem antes de começarmos o nosso primeiro romance, já tínhamos o hábito da literatura; parecia-nos natural que livros crescessem numa sociedade civilizada, como as árvores num jardim; foi por amar Racine e Verlaine que descobrimos em nós, aos catorze anos, na sessão noturna ou no pátio do liceu, uma vocação de escritor; (...)" (2004, p. 127). Tradução do Francês para o Português de Carlos Felipe Moisés

19 Assim escreve Sylvie Requemora sobre este fascínio: "As Américas e o seu exotismo ficam rápido na de outra nacionalidade - ou de uma outra formação cultural. Analisando o romance viático Voyage au bout de la nuit, obra maior do escritor Ferdinand Céline, o professor francês David Ravet usa os termos "alienação social" e "despersonalização" para se referir aos sentimentos percebidos pela personagem principal, Ferdinand Bardamu, na sociedade norte americana, e não faz referência ao termo culturalmente francês: o tédio (ennui) ${ }^{32}$. E é importante observar como este último, por sua vez, teme senti-lo:

Sempre receei estar um pouco vazio, de não ter, em suma, nenhuma razão séria para existir. Agora eu estava diante dos fatos e bem seguro do meu nada individual. Neste meio bem diferente daquele, no qual eu tinha hábitos mesquinhos, eu estava como dissolvido. Simplesmente, eu sentia como se não existisse. Assim, eu descobri que, quando paravam de me falar de situações familiares, nada me impedia de me prostrar em uma espécie de irresistível estado de tédio [ennui], em uma espécie de suave e terrível catástrofe da alma. Um desgosto33.

Trata-se de uma bela e dolorosa descrição do estado de tédio (ennui), o vague-à-l'âme, mas neste trecho não são os norte-americanos que se entediam, mas a personagem, um francês na América do Norte. Ora, é exatamente como no caso citado do arquiteto franco-suíço, e a lição que tiramos é que não se pode possuir um sentimento que não seja partilhado socialmente: o boring anglo-saxão soa de maneira muito diferente... E é justamente isto o que queremos indicar quando afirmamos que a frase de Sartre é, na realidade, um estereótipo, isto é, um topos do gênero viático. $E$ já que abordamos o estereótipo no texto Ville d'Amérique assim como em New York ville coloniale, talvez seja pertinente, a partir deste momento, analisar os outros topos aludidos na Introdução deste texto.

A narrativa de viagem está baseada na tríade "idaestadia-retorno" e este fato implicaria uma partida, assim como um trajeto, com a chegada, o itinerário e o retorno. Não encontramos esta tríade nas duas narrativas viáticas de Sartre, posto que a ida e o retorno são elipsadas, não existindo, como narrativa, senão a estadia. Estaríamos diante, então, de um processo que poderia ser nomeado de uma "desconstrução de um gênero literário" ? Ora, assim como o viajante-escritor, temos que nos guardar de todo exagero... Temos que pensar os textos nas suas especificidades, e neste caso, não é uma questão negligenciável o fato de que o seu primeiro fim foi o de ser uma matéria jornalística, e não um romance ou um livro de memórias. Neste sentido, e por economia de espaço, o seu autor teve que fazer as supressões necessárias, e isto significou o corte tanto da chegada quanto do retorno ${ }^{34}$.

Se esta estrutura básica do gênero viático não existe nos textos de Sartre, um outro importante topos está, em compensação, presente e perpassa todo o seu corpo: o "espanto". ${ }^{35}$ No início do texto Villes d'Amérique, no entanto, Sartre não se diz espantado: "Eu não tinha olhos para os arranhacéus e ele não me espantavam [étonnaient no original] [...]". ${ }^{36}$ Parece que o autor quis, intencionalmente, escapar a este importante topos viático; contudo, logo após ele se rende: "O que choca [frappe no original] é a extrema leveza, a fragilidade destas construções. "37 E adiante, colocase na posição de um hipotético cidadão europeu face à arquitetura norte-americana: "Em seguida, ele fica chocado [frappé no original] pela leveza dos materiais empregados." $38 \mathrm{E}$, ainda: "O que choca [frappe no original] nas cidades americanas é, sobretudo, a desordem em altura" ${ }^{\prime 39}$. Ora, como poderia um viajante não se espantar - e os seus mais diversos correlatos: se chocar, se surpreender etc - diante do desconhecido? Não seria, então, um viajante, mas um banal turista que não consegue ver senão aquilo que é imediatamente reconhecível, e isto não é, certamente, aplicável ao filósofo francês. Mas o que teria chocado tanto Sartre? Em poucas palavras, nós diríamos o que já havíamos, neste texto, escrito: o outro... Este sentimento de choque é justamente o resultado das viagens, a saber, o encontro com a alteridade, o contato com o alheio, com aquilo que não se é e se tem dificuldade em assimilar.

E, no caso dos textos que, ora, analisamos, este "outro" é a arquitetura e o urbanismo americanos. Sartre, com a sua experiência de deambulação nas mais diversas cidades européias, se espantou com a forma e os materiais de construção empregados nas cidades americanas. Neste sentido, é legítimo que nos perguntemos se o filósofo era completamente ignorante no que se refere ao caráter construído das cidades norte-americanas. Mas ele próprio nos confessa no texto New York ville coloniale: " 
moda nos meios intelectuais, desde o século XVI." Tradução nossa do Francês para o Português. No original lê-se: "Les Amériques et leur exotisme sont vite à la mode dans des milieux intellectuels, dès le XVle. siècle" (2002, p. 254).

20 "Mas qual é o lugar que a América do Norte, tomada em seu conjunto, ocupa ao certo? Se as obras de natureza exótica se multiplicam e se todos os lados do mundo estão presentes quando se foIheia romances, contos, jornais e, é claro, narrativas de viagem, a América ocupa incontestavelmente um lugar exótico original em todos estes escritos." Tradução nossa do Francês para o Português. No original lê-se: "Mais quelle place I'Amérique du Nord, prise dans son ensemble, detient-elle au juste? Si les ouvrages de nature exotique se multiplient et si toutes les contrées du monde sont présentes lorsqu'on feuillette des romans, des contes, des journaux et, bien sûr, des recits de voyage l'Amérique detient incontestablemrnt une place exotique originale dans tous ces écrits" (Bernadi, 1999, p. 13).

${ }^{21}$ Em uma entrevista concedida a Simone de Beauvoir em Agosto-Setembro de 1974 (portanto, dez anos após a publicação de As palavras) o filósofo francês afirma, ao comentar o seu imaginário infantil: "Minha vida devia ser uma série de aventuras, ou antes, uma aventura. Era assim que a via. A aventura passava um pouco em todo o lugar, mas raramente em Paris, porque em Paris é raro que se veja surgir um pelevermelha com pena na cabeça e uma arco nas mãos. Assim, a necessidade de aventuras obrigava-me a situá-las na América, na África, na Ásia. O continente europeu oferecia poucas oportunidades. Então, comecei a imaginar que iria para a América, que lutaria com os marginais, que teria êxito, que venceria alguns deles. E sonhei muito com isso." In: Beauvoir, Simone de. A cerimônia do adeus. Trad.: Rita Braga. Rio de Janeiro: Nova Fronteira, 1984, p. 314.

22 David Ravet faz uma espécie de estereótipos dos europeus em relação aos povos por eles colonizados: "Os
"Quando nós tínhamos vinte anos, por volta de 1925, nós ouvimos falar dos arranha-céus. Eles simbolizavam para nós a fabulosa prosperidade americana. Nós os descobrimos nos filmes com estupefação. Eles eram a arquitetura do futuro, assim como o cinema era a arte do futuro e o jazz a música do futuro." 40

Uma questão merece ser abordada neste trecho citado: o caráter coletivo da "descoberta". Não foi, naturalmente, apenas Sartre quem entrou em contato, "estupefato", com a arquitetura norteamericana, mas toda uma geração. Isto está claro até pelo uso da segunda pessoa do plural, afinal, quem diz "nós" diz coletivo, conjunto, todo. E é este, justamente, o caráter da descoberta do escritorviajante: as impressões sobre o outro apresentam um caráter tanto individual quanto coletivo, isto é, cultural. De qualquer sorte, este trecho nos deixa clara uma outra questão de suma importância, que é o caráter de "artifício" no espanto de Sartre; ora, como se espantar diante daquilo que, de alguma maneira já é conhecido? Assim, ganha sentido o que havíamos aludido: sob a sua narrativa há toda uma estrutura cultural que permitiu que ele relatasse o que viu.

É a partir deste topos que um outro se apresenta e se anuncia: a descrição dos lugares e dos hábitos observados em terras estrangeiras. E em quase toda esta literatura podem ser encontrados descrições e análises de hábitos e paisagens. Neste sentido, o que teria descrito o filósofo francês na América do Norte? Há, subjacente a esta pergunta, uma outra: o que ele teria percebido como importante o suficiente para, justamente, ser descrito? Como sabemos pelo título mesmo destes dois textos a arquitetura e o urbanismo americanos teriam causado este espanto e esta admiração. Mas este procedimento va sans dire... Bacon, no seu ensaio Da viagem - publicado pela primeira vez em 1597 , e no qual faz uma série de recomendações aos viajantes -, já não preconizava "ver e observar" a arquitetura?: "(...) as igrejas e os mosteiros, com os monumentos e documentos que por ventura conservem; as muralhas e as fortificações das cidades e vilas; (...)." 41 A lista de Bacon é longa e, naturalmente, não se restringe apenas à arquitetura, mas tem a vantagem de nos indicar que esta última é um tema recorrente nas narrativas de viagem, fazendo parte, por assim dizer, da "formação" do viajante ${ }^{42}$. Ora, Sartre conhecia arquitetura e o seu vocabulário plástico, e se, certamente, não era um especialista, esta não lhe era indiferente. Assim, teremos a oportunidade de fazer, nas próximas páginas, uma espécie de inventário das observações e análises que Sartre empreendeu nos dois textos que são objeto de nossa pesquisa.

\section{Sartre na América: um inventário da arquitetura e das cidades norte- americanas}

Antes de escrevermos sobre esta questão, importa visitar um outro topos das narrativas de viagem: o processo de assimilar o desconhecido comparandoo ao que já se conhece. E os textos do nosso corpus são, como o leitor já terá intuído, perpassados pela comparação: o autor francês reduz a arquitetura e as cidades americanas a partir da sua experiência de europeu. Convém afirmar, contudo, que este processo não se dá sempre da mesma maneira: há duas possibilidades, ou o filósofo francês compara a paisagem norte-americana a partir da paisagem urbana européia, em um processo que poderíamos nomear de "direto", ou tenta criar, no imaginário do leitor, aproximações com elementos que estes deveriam conhecer, mas que não são diretamente nem arquitetônicos nem urbanos; há, então, uma espécie de "mediação". Mas o fim é sempre o desejo de evocação no imaginário do leitor europeu de uma imagem urbana norte-americana. E para explicarmos com um pouco mais de precisão faremos uso do seguinte exemplo: "No fim de alguns dias deste regime, eu compreendi que uma cidade americana era, na origem, um acampamento no deserto." ${ }^{43} \mathrm{~A}$ imagem que Sartre evoca é àquela de um filme de Far West ${ }^{44}$, paisagem, reconhecêmo-lo, já bastante conhecida pelo público europeu. Outra comparação a que aludimos é a aproximação direta de realidades urbanas distintas:

É que o passado, nestas cidades que se formam rápido, que não são construídas para envelhecer e que progridem como os exércitos modernos, cercando quarteirões de resistência que eles não podem destruir, não se manifesta como em nós, como monumentos, mas como resíduos. ${ }^{45}$

O passado nas cidades norte-americanas é tão somente um traço, uma sobra, um resto que, um 
mitos coloniais, transmitidos não apenas pelas exposições, mas também pelos cartazes, pelas fotografias, pelos cartões postais, pelos cadernos escolares e pelos filmes, podem ser assim resumidos: pertencimento dos negros a uma raça inferior, representação da animalidade e do exotismo erótico das mulheres indígenas, idéia da selvageria e da bestialidade intrínseca aos africanos, desvalorização e estigma física das suas populações, afirmação da sua inferioridade intelectual e tecnológica e de sua ausência de cultura. Após o estabelecimento destes estereótipos, o colonizador pode explicar o seu papel e legitimizar as suas ações. Ele pode 'elevar' o indígena da sua posição inferior a um estágio superior de conhecimento, de técnica e de espiritualidade (o colonialismo estando estreitamente ligado à vontade do europeu de converter os negros ao Cristianismo)." Como se pode perceber, encontraríamos alguns destes estereótipos entre nós... Tradução nossa do Francês para o Português. No original lê-se: "Les mythes coloniaux, transmis non seulement par les expositions mais aussi par les affiches, les photographies, les cartes postales, les cahiers scolaires et les films, peuvent se résumer ainsi : appartenance des Noirs à une race inférieure, représentation de l'animalité et de l'exotisme érotique des femmes indigènes, idée de la sauvagerie et de la bestialité intrinsèques des Africains, dévalorisation stigmatisation physique de leurs populations, affirmation de leur infériorité intellectuelle et technologique et de leur absence de culture. Après l'établissement de ces stéréotypes, le colonisateur peut expliquer son rôle et légitimer ses actions. II veut " élever » I'indigène de son rang inférieur à un stade supérieur de connaissance, de technique et de spiritualité (le colonialisme étant étroitement lié à la volonté des Européens de convertir les Noirs au christianisme)."

${ }^{23}$ O termo Uncle Tom tem uma origem literária, tendo sido popularizado devido o romance Uncle Tom's Cabin, da norte americana Harriet Beecher Stowe. belo dia, será demolido. Para Sartre, este resíduo de passado, que pode tomar a forma de uma construção, de uma ponte, de trilhos de metrô de superfície, não tem nem jamais terá a dignidade de um monumento, como ocorre nas cidades européias. Ora, como se percebe, a comparação se dá entre modelos de cidades, entre uma hipotética cidade européia e o conjunto das cidades norteamericanas visitadas pelo filósofo francês.

Abordando, finalmente, a questão do inventário por nós proposto, não estaríamos longe da verdade se afirmássemos, de uma maneira geral, e pensando nas cidades, que o tecido urbano norte-americano teria chocado enormemente o nosso herói. As ruas são percebidas como "um pedaço de uma rodovia", "sem mistério" e, neste sentido, "não incitariam ao passeio." " 46 As pessoas nas ruas não passeariam nem flanariam, a sua relação com o urbano, segundo o filósofo francês, seria meramente "utilitária": do trabalho para a casa, da casa para o trabalho, passando sempre pelo underground. Quase poderíamos afirmar, a partir da leitura de nosso corpus, que os norte-americanos são turistas na sua própria cidade, uma vez que "dez blocks longe da sua casa se perdem". Estas observações foram, naturalmente, motivadas pela relação que Sartre possuía com as cidades européias. No seu diário escrito durante a Segunda Guerra Mundial, entre novembro de 1939 e março de 1940, e que foi publicado com o título de Cadernos de "Drôle de Guerre", Sartre afirma, ao se referir ao seu camarada Pieter: "Além disto, sinto em volta dele a poesia muito especial de um bairro de Paris que amo tanto quanto aos mais belos dos bairros". ${ }^{47} \mathrm{O}$ nosso autor relaciona pessoas a bairros, e escreve, um pouco mais adiante, quase com ressentimento:

Tudo isso era como um halo ao redor da cabeça de Pieter - o que era injusto! - porque para mim ele tinha a auréola de ter morado naquele bairro onde eu nunca passei de turista. Judeus entre judeus, vadio entre todos aqueles pequenos vadios que percorrem todas as noites as vizinhanças do Dupont da Bastilha. ${ }^{48}$ (destaque nosso)

A flânnerie em companhia de camaradas e amantes pela Rua des Francs-Bourgeois, pela Rua Vieille du Temple, pela Rua Rivoli e pela Rua des Rosiers são nostalgicamente evocadas, como em uma espécie de sonho no qual se mistura uma boa dose de memórias. É injusto que seu camarada Pieter, judeu polonês a serviço da França, tenha pertencido intimamente a um local tão cobiçado pelo amante Sartre, este "mero turista"... A menção no trecho citado tanto da figura do turista quanto a do judeu errante não é casual, posto que teriam ambas a função de demonstrar a ligação visceral sentida por Sartre entre locais e homens - a primeira personagem está fora da sua pátria e a segunda é um eterno expatriado... E o autor francês, no bairro amado, é um misto destas duas figuras. Neste sentido, é justamente esta relação tão próxima, tão íntima, que Sartre não percebe entre os norteamericanos e as suas cidades.

Sobrevoando o território dos Estados Unidos da América, Sartre espantou-se com a regularidade do traçado das cidades, as quais ele comparou a um "tabuleiro de damas", cujas peças seriam casas de madeira de um único piso. E, é claro, com uma rua principal que seria a sua "vértebra". Para o filósofo francês os Estados Unidos da América ainda estariam no mítico tempo do Far West, com a fundação de novas cidades a cada ano, com a mesma rapidez e facilidade com que se monta um acampamento. $\mathrm{E}$ tendo em mente estas cidades o nosso autor, que tinha bem presente a imagem de Ferdinand Céline Céline, das cidades "em pé" 49 , achou que uma cidade francesa era, em média, mais "alta" que uma cidade norte-americana. A imagem dos arranha-céus de New York e de Chicago foi ofuscada por uma realidade urbana quase decepcionante, como se tivessem the "pregado uma peça":

Quais são a impressões de um europeu quando ele desembarca em uma cidade americana? Inicialmente, ele se diz que Ihe pregaram uma peça. Falaram-Ihe dos arranha-céus de New York, de Chicago como "cidades em pé" [débout no original]. Ora, o seu primeiro sentimento, ao contrário, é que a altura média de uma cidade dos Estados Unidos é sensivelmente inferior a de uma cidade francesa. ${ }^{50}$

Como vemos, nas viagens o espanto pode ceder espaço à decepção, principalmente se o viajante já possuía no seu imaginário uma viagem idealizada. E já que nos referimos à extensão, é importante dizer que o nosso autor percebeu as distâncias entre as cidades - e mesmo nas cidades - como 
${ }^{24}$ Eis a referência completa: "É o suficiente para ornar com um pouco de suavidade a cidade mais rude do mundo". Tradução nossa do Francês para o Português. No original lê-se: "C'en est assez pour orner d'un peu de douceur la ville la plus rude du monde" (2002, p. 43).

${ }^{25}$ Tradução nossa do Francês para o Português. No original lê-se: "La nature pèse si lourdement sur New York que la plus moderne des villes est aussi la plus sale. [...] Quand je sors, je marche dans une neige noirâtre, sorte de croûte boursouflée de la même teinte que le trottoir, à croire que c'est le troittoir lui-même qui gondole" (2002, p. 38).

${ }^{26}$ Tradução nossa do Francês para o Português. No original lê-se: "Je crois camper au coeur d'une jungle grenouillante d'insectes" (2002, p. 38).

${ }^{27}$ Em relação à proximidade de parte da obra literária sartriana com a literatura norte americana Bernard Henri-Lévy tem a tese segundo a qual Sartre se utilizava das técnicas literárias criadas e desenvolvidas pelos escritores norte americanos - e principalmente dos Passos e Faulkner - com o claro intuito de se afastar da tradição literária francesa, e, principalmente, da tradição gideana (2000, p. 95).

28 "O estilo impregna os gestos cotidianos, sobrecarregaos, esmaga-os com uma magnificência de epopéia e os faz afundar como soldadinhos de chumbo. De caso pensado: é exatamente esta monotonia enjoativa e pomposa, esse ritual do cotidiano que Faulkner visa; os gestos são o mundo do tédio [ennui]. Esses indivíduos ricos, sem trabalho e sem lazeres, decentes e incultas, cativos em suas própria terras, senhores e escravos dos seus negros. Mas esse tédio (Faulkner terá sempre conseguido distinguir muito bem o dos seus heróis e o dos seus leitores?) é apenas uma aparência, defesa de Faulkner contra nós, dos Sartoris contra eles próprios. O tédio [ennui] é a ordem social, é o langor monótono de tudo o que se pode ver, ouvir, tocar: as paisagens de Faulkner se entediam tanto quanto suas personagens (2005, p. 30)." Tradução do Francês para o "grandes demais", e isto teria uma conseqüência importante: o pedestre norte-americano, para Sartre, é um homem que se desloca sempre através de máquinas: automóveis, metrô, ônibus, elevador, escada rolante - e isto, de alguma maneira, é percebido como um processo de "reificação" 51:

Do metrô à escada rolante, da escada rolante ao elevador, do elevador ao táxi, do táxi ao ônibus e, de novo, ao metrô e, em seguida, ao elevador; acontecia comigo, em alguns dias, de me sentir ser transportado como um pacote, de um endereço a outro sem ter tido de colocar um pé diante do outro. $^{52}$

Neste caso, a cidade, que segundo Lewis Munford foi o primeiro artefato fabricado pelo homem, nos Estados Unidos da América desumanizaria o homem: o filósofo francês viu-se na condição de objeto, de "coisa", um pacote transportado por máquinas. Por outro lado, esta relação de quase náusea ${ }^{53}$ que Sartre afirma ter sentido face aos deslocamentos mecânicos, tanto os horizontais quanto os verticais, pode ser interpretada como dépaysement, no sentido mesmo de estranheza e de desorientação face àquilo que é novo e "raro" 54.

Ora, os norte-americanos não flanam pelas suas "ruas de calçadas atrofiadas", apenas passam, para ir ao trabalho ou fazer compras, servindo-se do transporte mecânico. Não há dúvida de que a opinião de Sartre sobre as cidades norte-americanas é, preferencialmente, negativa. Teria, então, o nosso viajante se decepcionado e detestado a sua experiência urbana norte-americana? É uma boa pergunta, mas respondê-la afirmativamente neste momento seria, talvez, ir longe demais.

Mas, então, vejamos. Ao se referir ao fato de as cidades norte-americanas serem "leves" e "provisórias" - aliás, diferentemente das cidades européias -, Sartre chega ao ponto de conceder a estas uma certa admiração, que não era, ressaltese, muito entusiasmada: "No entanto, passa-se rapidamente a gostar das cidades americanas. [...] E depois, acaba-se por gostar do que elas têm em comum: esta aparência provisória. Sufoca-se um pouco em nossas cidades fechadas, cheias como ovos." 55 Para além do topos da comparação, cabe ressaltar as imagens criadas pelo filósofo francês: as cidades européias compreendidas como sendo fechadas, cheias, e o uso do termo "ovo" como metáfora; e a as cidades norte-americanas: leves, provisórias, frágeis, informes e inacabadas. Sartre refere-se ao imenso espaço geográfico que as cerca, a sua abertura - e como já vimos no caso da cidade de New York, a sua fragilidade - face a uma natureza que pode ser hostil. E, além disto, estas não são definidas, jamais tiveram as muralhas que cercavam e protegiam as cidades européias, e que, mesmo no século no qual Sartre escrevia, ainda serviam como pontos simbólicos de referência, e, por que não dizê-lo, como monumentos. As cidades norteamericanas, por sua vez, nunca tiveram um fuori muri... "Elas não oprimem, elas não fecham nunca: nada é definitivo nelas, nada está parado." ${ }^{56}$

Ainda a respeito deste tema, isto é, a relação do filósofo francês com as cidades norte-americanas, é possível reportarmo-nos a New York, "a cidade mais rude do mundo". Sartre, depois de alguns meses, teria passado a gostar dessa cidade: "Eu gosto de New York. Eu aprendi a gostar dela." ${ }^{57}$ Seria um amor profundo como o filósofo confessava nutrir pelas suas cidades favoritas, Paris e Veneza? Talvez para responder a esta pergunta devêssemos continuar a citá-lo: "Eu me acostumei com seus conjuntos maciços, com suas grandes perspectivas. Meus olhares não demoram mais sobre as fachadas em busca de uma construção que não fosse idêntica às outras." 58 Com a resignação de um amante frustrado que está constrangido a uma relação da qual não pode escapar, Sartre se conforma a gostar da grande metrópole norte-americana... Como se vê, um amor de pequeno burguês, mas quando se trata de Paris e de Veneza, isto é uma outra histoire...Sim, podemos dizer, então, que Sartre, de alguma maneira e em algum grau, apreciou a sua experiência viática norte-americana: era o espaço do encontro com o "outro", estas cidades estranhas, informes e inacabadas. Mas, ao menos no caso do filósofo francês, pode-se perceber que não é tarefa fácil gostar daquilo que é visto e conhecido sob o signo da alteridade.

Respondida esta questão, que não é de pouca importância na economia da nossa exposição, retornemos ao nosso inventário. Vimos as críticas que Sartre realizou à trama urbana das cidades norte-americanas que ele conheceu, e percebemos a sua origem e a sua motivação: um Narciso que não reconheceu a sua imagem na flor d'água de 
Português de Cristina Prado.

${ }^{29}$ Esta resposta de Sartre a Simone de Beauvoir resume admiravelmente a sua relação de conhecimento com os Estados Unidos da América: "Havia pensado muito na América, porque... em primeiro lugar, quando criança, os Nick Carter e os Buffalo Bill me remetiam a uma determinada América, que depois conheci melhor através dos filmes; li os romances do grande período moderno, isto é, tanto Dos Passos quanto Hemingway." In: Beauvoir, Simone de. A cerimônia do adeus. Trad.: Rita Braga. Rio de Janeiro: Nova Fronteira, 1984, p. 323.

30 Desde o spleen baudelairiano até o livro de Émile Tardieu, L'ennui, este topos já fez correr rios de tinta, apresentando as mais diversas faces. Há mesmo o caso na própria obra de Sartre: a novela La nausée teve como primeiro título Melancholia (2000, p. 41).. $E$, convém acrescentar, mesmo que seja a título apenas de informação, que Sartre não era conhecido, exatamente, como alegre. A revista francesa L'Express publicou uma capa na qual dominava a foto do escritor François Mauriac com a seguinte legenda: "O Sartre pourquoi êtes-vous si triste?" Mas é claro que nem melancolia nem tristeza são bons sinônimos para o termo tédio (ennui), e nem a revista francesa serve de um apoio para as nossas argumentações, e, justamente por isto, envio o leitor ao capítulo $O$ tédio, $O$ eterno retorno, de Walter Benjamin, em: Passagens. Belo Horizonte: Editora UFMG, São Paulo: Imprensa Oficial, 2007.

${ }^{31}$ Tradução nossa do Francês para o Português. No original lê-se: "Les restauronts américains sont silencieux" (1936, p. 148). "Je m'ennui, j'ai le temps d'observer " (1936, p. 151).

${ }^{32}$ New York chez Céline et Hopper: une esthétique de la démythification du rêve américain. In: Astrolabe, $n^{\circ} 2$, junho 2006.

${ }^{33}$ Tradução nossa do Francês para o Português. No original lê-se: "Toujours j'avais redouté d'être à peu pres vide, de n'avoir em somme aucune raison sérieuse pour um lago. Mas vimos, igualmente, que havia na postura do filósofo francês, certamente um grande viajante, uma tentativa de compreensão da realidade estrangeira que se apresentava, e isto significa que havia uma abertura para o outro. Mas já escrevemos sobre as cidades norte-americanas descritas pela ótica de um europeu, seria importante, neste momento, voltar ao topos do espanto e escrever sobre a maneira pela qual Sartre apreendeu a arquitetura do país que havia visitado.

Em Fontana, Tennessee, pequena cidade composta por três aglomerações urbanas, duas destinadas aos brancos e uma destinada aos negros ${ }^{59}$, Sartre espantou-se com casas pré-fabricadas, cuja fatura das peças se dava a mil quilômetros dali. Ele as comparou a "cabines", como as cabines de um navio ou cabines telefônicas: "No interior, com os seus móveis em série, o seu aquecimento central, as suas lâmpadas elétricas, as suas geladeiras, fazem pensar em cabines. Cada polegada destas pequenas peças de aspecto anti-séptico foi utilizada: há armário nas paredes e gavetas sob a cama." 60 Esta citação faz-nos pensar nas propostas de muitos arquitetos modernistas, inclusive naquelas do franco-suíço Le Corbusier: os móveis em série, as casas préfabricadas, a relação entre os artefatos industriais e a construção civil etc. Sartre, no entanto, não tinha a arquitetura no centro das suas preocupações - e talvez nem mesmo nas margens... -, escrevia sobre arquitetura na condição de um viajante-escritor e não de um especialista, e, sobretudo, e esta é uma questão importante, ele não estava escrevendo para arquitetos e sim para um "público geral" leitor de jornais. Ora, os arquitetos franceses já conheciam esta arquitetura pelas revistas Architecte e Architecture d'Aujourd'hui e não precisavam ser informados por um filósofo; de qualquer sorte, a "modernidade" dos Estados Unidos da América sempre fascinou os europeus, e Sartre estava apenas reproduzindo um padrão: ver, conhecer e descrever as tais "coisas raras" 61 .

De mais valia é analisar os desdobramentos, no próprio texto, das observações de Sartre: “(...) eis uma cidade, ou, melhor, uma matriz da cidade americana, com todos os seus órgãos essenciais: embaixo um uniprix, mais para o alto uma clínica, no cume uma igreja "mista", na qual se faz um serviço mínimo, isto é, válido para todas as religiões." 62 Segundo o filósofo francês, esta "cidade viajante" [ville baladeur no original] pode ser desmontada quando necessário e ser remontada em outro lugar, e mesmo em outro estado, em torno de um poço de petróleo ou de uma plantação de algodão. Para um europeu, Fontana não é uma cidade como as suas casas já não eram "arquitetura": cabines sobre rodas que compõem um "acampamento no deserto". Assim, não é de se espantar que Sartre tenha se surpreendido com a "fragilidade" desta arquitetura - como antes já tinha ficado surpreso com a fragilidade das cidades -, afinal, são provisórias e podem não durar. "Detroit e Minneapolis, Knoxville, Memphis nasceram provisórias e permaneceram"63, tantas outras, contudo, partiram sobre rodas sem deixar rastro... O filósofo francês estava diante de uma paisagem urbana móvel, e o uso do termo matriz não é de pouca importância; ora, pode-se depreender que a sua compreensão da cidade norte-americana ainda passava pelos mitos da infância: toda cidade, um dia, foi um cenário mítico do Far West...

Sartre afirma, ainda, que esta arquitetura não pesa sobre o solo, sendo leve demais para marcar a terra. E esta apreensão o levou a uma outra consideração importante, a diferença entre home e house. O que Sartre percebeu, é que a house para um norteamericano é tão somente uma "carcaça" provisória que pode ser abandonada sem nenhuma misericórdia, posto que o que realmente importa é a home, o conjunto de objetos, móveis, fotos, tudo aquilo, enfim, a que se permite alguma afeição. Esta observação é curiosa se pensaremos que o seu autor, na sua condição de anti-burguês, gabavase de possuir como propriedade apenas o seu cachimbo, a sua única home...

Contudo, em relação as houses, Sartre não tinha muitas opiniões favoráveis a emitir, tendo guardado para elas os epítetos nada elogiosos de "maison de pacotille", "bicoques" e "maisonettes". Ora, se pensarmos que bicoque significa uma casa sem valor, e que o termo francês pacotille indica uma mercadoria de pouco custo, veremos bem a depreciação destas casas na percepção do filósofo francês... E uma das razões era, justamente, o material de construção utilizado, e, neste caso, a madeira: 
exister. A présnet j'étais devant les faits bien assuré de mon néant individuel. Dans ce milieux trop différent de celui ou j'avais de mesquines habitudes, je m'étais comme dissous. Je me sentais bien pres de ne plus exister, tout simplement. Ainsi, je le découvarais, dès qu'on avait cesse de me parler des choses familières, plus rien ne m'empêchait de sombrer dans une sorte d'irresistible ennui, dans une manière de doucereuse, d'effroiable catastrophe d'âme. Une dégoutation" (1974, p.205)

${ }^{34}$ Não se trata, neste artigo, de estudar textos exteriores ao nosso corpus para buscarmos uma dimensão que pudesse ser compreendida como "mais completa" da experiência viática de Sartre com os Estados Unidos da América; no entanto, a título de curiosidade, envio o leitor às páginas 323-331 do já citado livro de entrevistas, nas quais o filósofo francês discorre, às vezes com detalhes, sobre a sua viagem de 1945 aos Estados Unidos da América; neste texto pode-se ler sobre o transporte, o hotel, a sua relação tanto com os norte-americanos quanto com os franceses exilados etc. In: Beauvoir, Simone de. A cerimônia do adeus. Trad.: Rita Braga. Rio de Janeiro: Nova Fronteira, 1984.

35 Já abordamos esta questão no artigo de nome Sartre na América ou memórias de um bourgeois épaté, publicado no periódico Revista de Arquitetura e Urbanismo-PUC Minas, no ano de 2006.

${ }^{36}$ Tradução nossa do Francês para o Português. No original lê-se: "Je n'avais pas l'oeil fait aux gratte-ciel et ils ne m'étonnaient pas (...)."

${ }^{37}$ Tradução nossa do Francês para o Português. No original lê-se: "Ce qui frappe c'est la légèreté, la fragilité de ces bâtiments" (2002, p. 18)

38 Tradução nossa do Francês para o Português. No original lê-se: "Ensuite, il est frappé par la légéreté des materiaux employés" (2002, p. 23).

${ }^{39}$ Tradução nossa do Francês para o Português. No original lê-se: "Ce qui frappe surtout dans les villes américaines, c'est le désordre em hauteur" (2002, p. 27).
Mesmo nas cidades mais ricas e nos bairros mais elegantes destas cidades, é freqüente encontrar casas de madeira. As belas residências coloniais de Nova Orleans são em madeira; em madeira os belos chalés onde moram as estrelas e os diretores de Hollyhood; em madeira o cottage "estilo californiano" de São Francisco; em todos os lugares você encontrará grupos de casas de madeira esmagadas entre dois edifícios de vinte pavimentos. ${ }^{64}$

Esta enumeração que lembra um catálogo nos remete à percepção de Sartre sobre a arquitetura norteamericana; ora, ele a percebe como exótica - e importa afirmar que a menção às "estrelas e aos diretores de Hollyhood" não é casual, posto que aumentaria no imaginário do leitor europeu a sensação de exotismo - mas, se no caso das casas pré-fabricadas o exotismo estava ligado principalmente ao processo construtivo, neste caso este está diretamente ligado ao material com o qual estas maisonettes foram construídas: a madeira. Em ambos os casos, porém, se trata do mesmo espanto diante da sua leveza face às "sólidas" e "permanentes" casas européias. Ora, tudo na paisagem urbana norte-americana era visto como móvel e provisório, Fontanas e mais Fontanas se repetiam no imaginário sartriano, como peças de madeira em uma trama xadrez. "Nós mudamos em cidades imutáveis e nossas casas e os nossos bairros sobrevivem a nós; as cidades americanas mudam mais rápido que os seus habitantes e são eles que sobrevivem a elas." ${ }^{65}$

Tínhamos alhures afirmado a importância da comparação na literatura de viagens, e quando Sartre quer referenciar o seu leitor e partilhar com eles a sua opinião sobre a arquitetura americana, ele evoca as cidades francesas de balneários de Cabourg, Trouville e Baule - e que, nesta condição, estão associadas tanto a viagens quanto a turismo: "Só estes efêmeros chalés na beira do mar, com a sua arquitetura pretensiosa e a sua fragilidade, podem dar uma idéia das residências americanas àqueles dos meus leitores franceses que não viram os Estados Unidos." 66 Acrescenta, ainda, que esta arquitetura dá a impressão de uma "cidadeexposição" que, tendo sobrevivido mais do que o devido, teria uma aparência de solenidade e, ao mesmo tempo, de penúria. Como podemos perceber, a comparação está sempre baseada na fragilidade e, sobretudo, no provisório.

\section{Últimas considerações}

Para concluir este artigo e o nosso inventário, uma redundância: as cidades européias possuem um longo passado que ficou materializado em inúmeros vestígios materiais, os quais têm o estatuto de monumento. Escrevemos esta frase como contexto para a definição que Sartre emprega para caracterizar as cidades européias: "cidade-museu", isto é, uma cidade que, em si mesmo, na sua estrutura material, já é um monumento histórico. Esta definição serve para caracterizar negativamente a grande metrópole norte-americana: "New York não é uma cidade museu; (...)" .67 O que o filósofo francês explica ao seu leitor é justamente este caráter de mudanças bruscas e de um certo desdém pelo antigo, que, segundo ele, estabelecem as relações entre os norteamericanos e as suas cidades. Os europeus, ao contrário, se orgulhariam de suas "velhas cidades": "Nós gostamos das cidades-museus - e todas as nossas são um pouco como museus onde nós erramos entre as moradas dos nossos ancestrais. "68 Esta bela frase indica claramente a preferência de Sartre, e o amor devotado por ele a Paris e a Veneza no-lo atesta. O amor pela Itália e por suas cidades - mas, principalmente por Veneza -, pode ser atestado com a leitura do seu livro póstumo $A$ Rainha Albermale ou o último tourista, ${ }^{69}$ no qual um viajante solitário erra pelas ruas romanas e venezianas, colhendo aqui e acolá impressões do urbano e da arquitetura italianas. E não é sem importância o fato de que Sartre, no seu último ano de vida, já bastante debilitado e quase cego, pediu que o levassem a Veneza, para ver e ouvir esta cidade uma vez mais...

\section{Referências Bibliográficas}

Apollinaire, Guillaume. Alcools. Paris: Nathan, 1983.

Bacon, Francis. Ensaios. Trad.: Álvaro Ribeiro. Lisboa: Guimarães Editores, 1992.

Beauvoir, Simone de. A força da idade. Trad.: Sérgio Millet. Rio de Janeiro: Nova Fronteira, 1984.

A cerimônia do adeus. Trad.: Rita Braga. Rio de Janeiro: Nova Fronteira, 1984.

Benjamin, Walter. Passagens. Trad.: Irene Aron, Cleonice Paes Barreto Mourão, Patrícia de Freitas Camargo. Belo Horizonte: UFMG, São Paulo: Imprensa Oficial do Estado de São Paulo, 2007.

Céline, Ferdinand. Voyage au bout de la nuit. Paris: Gallimard, 1952. 
Fernandez, Bernard. L'homme et le voyage, une connaissance éprouvée sous le signe de la rencontre. Em: Barbier, R. (Org.). Education et sagesse: la quête du sens. Paris: Albin Michel, 2001.

Fulton, Ann. Apostles of Sartre - Existentialism in America, 1945-1963. Evanston: Northwestern University Press, 1999.

Jannière, Hélène. Politiques éditoriales et architecture "moderne". Paris: editions Arguments, 2002.

Jeanson, Francis. Sartre. Paris: Seuil, 2000.

Le Corbusier. Quand les cathédrales étaient blanches. Paris: Plon, 1936

Lévy, Bertnard-Henry. O século de Sartre. Trad.: Jorge Bastos. Rio de Janeiro: Nova Fronteira, 2000.

Lima, Adson Cristiano Bozzi Ramatis Lima. Sartre na América ou memória de um "bourgeois épaté. In: Cadernos de Arquitetura e Urbanismo PUC-Minas, v. 13, 2006

Ravet, David. Le voyage chez Nizan et Céline: une esthétique de la subversion et de la contre-culture. In: Astrolabe, n³, julho 2006.

. New-York chez Céline et Hopper: une esthétique de la démythification du rêve américain. In: Astrolabe, $n^{\circ}$ 02, junho 2006.

Requemora, Sylvie. L'espace dans la littérature de voyages. Em: Etudes Littéraires, v. 34, nº. 1-2, 2002, p. 249-276. URL: http//id.erudit.org/iderudit/ 0075666ar.

Sartre, Jean-Paul. Situações I. Trad.: Cristina Prado. São Paulo: CosacNaif, 2005.

Diário de uma guerra estranha. Trad. : Aulyde Soares R odrigues. Rio de Janeiro: Nova Fronteira, 1983

L'âge de raison. Paris: Gallimard, 1983.

A nausea. Trad.: Rita Braga. Rio de Janeiro: Nova Fronteira, s.d.

La reine Albermale ou le dernier touriste. Paris: Gallimard, 1991

O que é a literatura? Trad.: Carlos Felipe Moisés. São Paulo: Ática, 2004.

Villes d'Amérique; New York, ville coloniale; Venise, de ma fenêtre. Paris: Editons du patrimoine, 2002.

As palavras. Trad.: J. Guisburg. Rio de Janeiro: Nova Fronteira: 1984.

Saint-Exupéry, Antoine de. Escritos de guerra. Trad.: Vera Guimarães Duarte. Rio de Janeiro: Nova Fronteira, 1984.

\section{Notas do autor (continuação)}

${ }^{40}$ Tradução nossa do Francês para o Português. No original lê-se: "Quand nous avions vingt ans, vers 1925, nous avons entendu parler des gratte-ciel. Ils symbolisaient pour nous la fabuleuse prosperité américaine. Nous les avons découverts avec stupéfaction dans les films. Ils étaient l'architecture de l'avenir, tout comme le cinema est l'architecture de l'avenir et le jazz l'architecture de l'avenir" (20002, p. 42)

${ }^{41}$ (1992, p. 81). Tradução do Francês para o Português por Álvaro Ribeiro.

42 Sartre parece concordar com o filósofo inglês: "A viagem é a descoberta de cidades e de paisagens, as pessoas vêm depois." In: Beauvoir, Simone de. A cerimônia do adeus. Trad.: Rita Braga. Rio de Janeiro: Nova Fronteira, 1984, p. 316.

43 Tradução nossa do Francês para o Português. No original lê-se: "Au bout de quelques jours de ce regime, j'ai compris qu'une ville américaine était, à l'origine, um campement dans le désert" (2002, p. 16).

44 "Mas estas cidades leves, tão semelhantes ainda a Fontana, aos acampamentos de Far West (...)." (Tradução nossa do Francês para o Português. No original lê-se: "mais ces villes légères, si semblables encore à Fontana, aux campements de Far West (...)" (2002, p. 30)

45 Tradução nossa do Francês para o Português. No original lê-se: "C'est que le passée, dans ces villes qui vont vitr, quin e sont pás construites pour vieillir et q1ui progressent comme des armées modernes, em encerclant les îlots de résistence qui elles ne peuvent détruir, ne se manifeste pas, como chez nous, par des monuments, mais par résidus" (2002, p. 26 - destaques do autor)

46 Tradução nossa do Francês para o Português. Eis a referência completa na língua original: "La rue américaine est um tronçon d'une grand'route. Elle s'étend parfois sur plusieurs kilomètres. Elle n'incite pas à la promenade: les nôtres sont obliqúes, tortueuses, pleines de replis et de secrets" (2002, p. 28).

47 Cadernos de uma Guerra Estranha. Rio de Janeiro: Nova Fronteira, 1983, p. 152. Tradução do Francês para o Português de Aulyde Soares Rodrigues.

${ }^{48}$ Cadernos de uma Guerra Estranha. Rio de Janeiro: Nova Fronteira, 1983, p. 152. Tradução do Francês para o Português de Aulyde Soares Rodrigues.

${ }^{49}$ Ao chegar a New York Bardamu exclamou: "Imaginem que em é em pé a cidade deles, absolutamente reta". Tradução nossa do Francês para o Português. No original lê-se: "Figurez-vous qu'elle était debout leur ville, absolutement droite ( 1952, p. 186). Le Corbusier, na metrópole americana, repete a personagem criada por Céline: "New York é uma cidade em pé, sob o signo dos novos tempos." Tradução nossa do Francês para o Português. No original lê-se: "New York est une ville debout, sous le signes des temps nouveaux" (1936, p. 51).

${ }^{50}$ Tradução nossa do Francês para o Português. No original lê-se: "Quelles sont les impressions d'Européen lorqu'il débarque dans une cite américaine? D'abord, il se dit qu'on lui a monte le coup. On ne lui parlait que des gratte-ciel, on lui présentait New York, Chicago comme des 'villes débout'. Or son premier sentiment, au contraire, est que la hauteur moyenne d'une ville des États-Unis est sensiblement inférieure à celle d'une ville française" (2002, p. 23).

51 Esta conclusão pode parecer "apressada", e o uso do termo "reificação" pode soar arbitrário, no entanto, estamos nos fiando no ensaio do próprio Sartre intitulado O homem e as coisas, no qual ele analisa a poética de Francis Ponge: "Quando Ponge quer beneficiar e fazer beneficiar aos outros os sentimentos que ele julga reclusos no âmago dos objetos, isso não significa que ele faça das coisas homenzinhos silenciosos, mas antes que toma os homens deliberadamente como coisas" (2005, p. 248). Tradução do Francês para o Português de Cristina Prado. Tivemos em mente, igualmente, a interpretação de David Ravet do romance de Céline Voyage au bout de la nuit, o qual Sartre conhecia.

52 Tradução nossa do Francês para o Português. No original lê-se: "De métro em escalier roulant, d'escalier roulant em ascenseur, d'ascenseur em táxi, il m'est arrivé, em certains jours, d'être emporté comme um colis d'um rendez-vous à um autre rendezvous sans mettre um pied devant l'autre" (2002, p. 29). 
${ }^{53}$ Usamos este termo, de extrema fortuna crítica na literatura sartriana a partir da novela que tem este conceito no seu título, justamente porque o filósofo francês o usa para se referir ao seu sentimento nos elevadores de New York.

${ }^{54}$ Este é um outro topos de grande importância no gênero viático, o dépaysement que muitos viajantes-escritores representam. O sentimento do lar deixado para trás aliado à visão da paisagem estrangeira causam este sentimento de nostalgia que tanto evoca a rememoração quanto por ela é provocada. Optamos por conservar a expressão na língua francesa e, por conseguinte, por não traduzi-la por termos como "mudança", "nostalgia" ou mesmo "saudades", porque nesta palavra está inscrito pays, cuja tradução por "país" não contempla todas as possibilidades e alcances do original. Ora, pays significa, certamente, país, mas também é sinônimo de região, vila, localidade e até mesmo - e é este sentido aquele que mais nos interessa - lugar de origem. 0 dépaysement significa, e mesmo etimologicamente, estar fora do seu local de origem e todas as conseqüências que este fato acarreta: nostalgia, desorientação e estranheza.

${ }^{55}$ Tradução nossa do Francês para o Português. No original lê-se: "Pourtant on met rapidement à aimer les villes d'Amérique. [...] Et puis on finit par aimer ce qu'elles ont em commun: cet air de fragilité" (2002, p. 30)

${ }^{56}$ Tradução nossa do Francês para o Português. No original lê-se: "Elles n'oppressent pas, elles n'enferment jamais: rien n'est définitif em elles, rien n'est arrêté" (2002, p. 30).

${ }^{57}$ Tradução nossa do Francês para o Português. No original lê-se: "J'aime New York. J'ai appri à l'aimer" (2002, p. 39).

${ }^{58}$ Tradução nossa do Francês para o Português. No original lê-se: "Je me suis habitué à ses ensembles massifs, à ses grandes perspectives. Mes regards ne s'attardent plus sur les façades em quête d'une qui, par impossible, ne serait pas identique à toutes les autres" (2002, p. 39).

${ }^{59}$ Em 1945, o marxista que Sartre seria (e posteriormente comunista pró União Soviética e depois maoísta) ainda estava em fase embrionária, e nos dois textos de nosso corpus nem uma palavra foi escrita sobre a desigualdade racial e a situação dos negros nos Estados Unidos da América. A primeira referência a esta importante questão encontra-se no livro intitulado O que é a literatura, publicado pela primeira vez em 1948. No texto Villes d'Amérique ele constata: "Foram residências aristocráticas, agora pobres as habitam. Há destes templos greco-romanos no sinistro bairro negro de Chicago; do lado de fora ainda tem boa aparência, no interior, doze famílias negras, comidas por pulgas e ratos, amontoam-se em cinco ou seis cômodos" (2002, p. 30). Mas que o leitor não se engane, trata-se tão somente de uma constatação, e não de uma condenação, ainda estamos muito distante da denúncia da "negrofobia americana" do O que é a literatura (ver p. 210). Por volta de 1951, já completamente rompido com os Estados Unidos da América, ele escreveu: "Diferença entre segregação americano (os pretos estão no canto deles) e nossa doçura para os Negros (o mar nos separa deles, pode-se honrar aqueles que vêm)." Tradução nossa do Francês para o Português. No original lê-se: "Différence entre ségrégation américaine (les nègres sont chez eux) et notre douceur pour les Noirs (la mer nous en separe, on peut honorer ceux qui viennent" (1991, p. 180).

60 Tradução nossa do Francês para o Português. No original lê-se: "Au dedans, avec leurs meubles em série, leur chauffage central, leurs lampes electriques, leurs frigidaires, elles font penser en cabines" (2002, p. 17)

61 Referindo-se a revista Architecture d'Aujourd'hui a pesquisadora francesa Hélène Jannière afirma: "A presença da cena americana se afirma em 1930 e 1931 sob a forma um pouco conveniente de um tipo espetacular, o aranha-céu. Em seguida, ela se enriquece de aproximações mais originais, menos difundidas na França: o urbanismo americano é filtrado através do olhar de arquitetos franceses (Eugène Beaudoin, depois Le Corbusier). No número 9 de 1933 Beaudoin comenta os planos de urbanismo americanos no século XIX, e o de Burnham para Chicago (1909). Na segunda metade dos anos trinta, a revista apresenta uma visão original e mais contemporânea: ela aborda, então, a questão da estandardização, as tecnologias de construção leve, desmontáveis ou a baixo custo, o primeiro sistema de combinação de alojamentos em duplex, ou, por ocasião dos dossiês temáticos, o exame de tipologias particulares como os hospitais e as escolas." Tradução nossa do Francês para o Português, No original lê-se: "La présence de la scène américaine s'affirme en 1930 et 1931 sous la forme un peu convenue d'un type spétaculaire, le gratte-ciel. Elle s'enrichit ensuite d'approches plus originales, moins diffusées en France: I'urbanisme américain est filter à travers le regard d'architectes français (Eugène Beaudoin, puis Le Corbusier). Dans le neméro 9 de 1933 Beaudois commente les plans d'urbanisme américain au XIXe. Siècle, et celui de Bunrham pour Chicago (1909). Dans la seconde moitié des années trente, la revue apporte une vision originale et plus contemporaine: elle aborde alors la question de la standardization, les technologies d construction légère, démontables ou à faible coût, le premier système combinatoire de logement en duplex,ou, à l'occasion des dossiers thématiques, l'examen de typoplogies particulières telle que les hôpitaux ou les écoles." (2002, p. 191). E sobre a revista L'Architecte: "L'Architecte mostra a sua preferência por uma América que era sinônimo de novos procedimentos construtivos, de organização racional do canteiro de obras e de novos programas, os mais aptos a seus olhos de evocar a modernidade arquitetônica." Tradução nossa do Francês para o Português, No original lê-se: "L'Architecte affiche as préférence pour une Amérique synonime de nouveaux procedes constructifs, d'organization racionelle du chantier et de nouveaux programmes, les plus aptes à ses yeux à évoquer la modernité architecturale" (2002, p. 221). Ou seja, se nos fiarmos em Jannière os arquitetos franceses se encontravam bem informados da arquitetura americana das décadas de 1930 e 1940.

62 Tradução nossa do Francês para o Português. No original lê-se: "(...) voilà une ville ou plutôt une matrice de ville américaine, avec toutes ses organes essentiels: em bas um uniprix, plus haut la clinique, au sommet une église 'mixte' ou l'on fait ce qu'on pourrait appeller un service minimum, c'est-à-dire valabre pour toutes les confessions" (2002, p. 17)

${ }^{63}$ Tradução nossa do Francês para o Português. No original lê-se: "Detroit et Minneapolis, Knoxville, Memphis sont nées provisoires et sont restées" (2002, p. 19).

64 Tradução nossa do Francês para o Português. No original lê-se: "Même dans les cités les plus riches et dans les quartiers les plus élégants de ces cités, il est fréquent de trouver des maisons de bois. Les belles demeures coloniales de la Nouvelle-Orléans sont em bois; en bois beaucoup des jolis chalets ou habitent les stars et les metteurs-em-scène d'Hollyhood; en bois le cottage 'style californien' de San-Francisco; partout vous recontrerez des groupes de maisons de bois écrasé entre deux building de vingt étages" (2002, p. 23)

${ }^{65}$ Tradução nossa do Francês para o Português. No original lê-se: "Nous, nous changeons dans des villes imuables et nos maisons, nos quartiers nous survivent; les villes américaines changent plus vite que leurs habitants et ce sont eux qui leur survivent" (2002, p. 21)

${ }^{66}$ Tradução nossa do Francês para o Português. No original lê-se: "Seuls, ces éphémères chalets au bord de la mer, avec leur architecture prétencieuse et leur fragilité peuvent donner une idée des immeubles américains à ceux de mes lecteurs qui n'ont pas vu les États-Unis" (2002, p. 24).

${ }^{67}$ Tradução nossa do Francês para o Português. No original lê-se: "New York n'est pas une ville-musée; (...)" (2002, p. 41).

${ }^{68}$ Tradução nossa do Francês para o Português. No original lê-se: "Nous aimons des villes-musées - et toutes nos villes sont un peu comme des musées ou nous vagabondons parmi les demeures de nos ancêtres" (2002, p. 41).

69 La reine Albermale ou le dernier touriste - fragments. Paris Gallimard, 1991. Este livro é o resultado de um projeto literário de Sartre que foi abandonado, como indica o subtítulo, incompleto. A edição foi organizada pela sua filha adotiva Arlette Elkaim-Sartre. 


\title{
Imago Mundi: a escritura do mundo - as cidades norte-americanas sob o olhar de Jean-Paul Sartre
}

\author{
Adson Cristiano Bozzi Ramatis Lima
}

\begin{abstract}
This article will exanimate two texts written by the French philosopher Jean-Paul Sartre, namely, New York City and colonial and Cities of America, written after a trip to the United States of America, token by the author in the year of 1945. These texts are the only works of French philosopher dealing, almost exclusively, the theme of architecture and urbanism. On the other hand, Its are a specific literary genre, so-called "travel narrative" or "travel literature", and this condition has a specific code and its own regulations. Accordingly, we list and describe their topos more frequent, as the "comparison" and the "amazement", thinking that a trip is always the opportunity of meeting with the otherness. After that, we analyzed the comments that the French philosopher did about the architecture and cities of United States of America.
\end{abstract}

Keywords: north american cities, north american architecture, french philosophy. 